\title{
КОНФЛИКТОЛОГИЯ
}

UDC $111+141.32$

\section{The nature of conflict: Ontological paradox and existential effort of acceptance}

\author{
E. V. Biricheva \\ Institute for Philosophy and Law, Ural Branch, Russian Academy of Sciences, \\ 16, ul. S. Kovalevskoi, Ekaterinburg, 620219, Russian Federation
}

For citation: Biricheva E.V. The nature of conflict: Ontological paradox and existential effort of acceptance. Vestnik of Saint Petersburg University. Philosophy and Conflict Studies, 2019, vol. 35, issue 4, pp. 607-625. https://doi.org/10.21638/spbu17.2019.407

This paper investigates the fundamental nature of conflict within an existential-phenomenological approach. Despite extensive research having been carried out on the phenomenon of conflict, little attention has been paid to its correlation with the ontological paradox. In this context, the present paper attempts to locate a uniform ground for an understanding of the entity of conflict by means of rethinking the specific position of man within Being. This becomes possible through the unfolding of a complex existential-phenomenological methodology consisting of a description of participants experiencing the paradoxical nature of conflict. Conflict is sure to consist of an encounter between opposites, incompatibilities or contradicting parties. However, where do these opposites originate and where are these contradicting parties located? The search for answers reveals that ignoring (avoidance) an understanding of the situation, as well as a rush to an immediate resolution of the conflict, appears to be unproductive. One of the possible solutions might be found within the ontological paradox in terms of phenomenological attentive consideration and existential effort for accepting the insolvability of a conflict. Nevertheless, this way reveals a paradoxical path for productively dealing with the nature of human conflict, allowing a thorough understanding in the categories of finitude, entirety, "inner war," self-state and effort of acceptance. This complex approach may be further applied within both philosophical and sociopolitical research areas based on the represented categories. For example, investigations of such phenomena as crisis, habit, change, innovation, etc., are of great interest in terms of harmonisation of self-state and effort for acceptance.

Keywords: conflict, nature of conflict, existential-phenomenological approach, ontological paradox, effort of acceptance.

(c) Санкт-Петербургский государственный университет, 2019 


\section{Introduction}

The phenomenon of conflict has received much attention within diverse disciplines in recent years, primarily as a consequence of the escalation of contemporary international conflicts. The word "conflict" has a Latin origin and in the broadest sense may be considered as a "hassle," which is characterised by the presence of contradiction taking the form of disagreement. Extensive psychological, sociological, political, economic, linguistic and cultural research has been carried out in order to classify conflicts, identify their causes and find ways to manage conflict situations that arise [1-4]. However, despite the abundance of theories and methodologies within conflict studies, researchers remain in serious disagreement concerning the dangers and benefits of conflicts, approaches to overcoming them, similarities and differences between conflicts of diverse scales, etc. This lack of unity in conflict-related discourse may be due to a lack of clarity concerning the nature of conflict [5, p.531]. Philosophical research, which aims at clarity in discussing the fundamental nature of things, may therefore yield insights concerning the essential nature of conflict.

The phenomenon of conflict has been investigated since ancient times, with classical Greek thinkers such as Thucydides and Plato, in particular, providing a perspective on conflict within discussions related to human nature. In his History of the Peloponnesian War, Thucydides drew attention to an interesting feature of the conflict between the peoples of Athens and Sparta, distinguishing the underlying reasons for their enmity from the discrete occasions that gave rise to the declaration of war. Thucydides came to the conclusion that the true causes of conflict reside in human vices such as envy, fear, lust for power and acquisitiveness [6, p. 2-43]. Then, is the entity of conflict rooted in human nature? Plato approaches this question in such works as First Alcibiades, Republic, Laws, etc. [7-9]. In the light of the understanding of Being as Good - and considering questions of justice, injustice and obligation - Plato discusses the causes of disagreement between people even within the same city-state. The medieval tradition, in reconstructing the Platonic and Aristotelian understanding of Good within the concept of creationism, conceives conflict in terms of the inner struggle of opposing conceptions of virtue and evil and those of sin and desire for the salvation of the soul [10-12]. During the secularisation and refocusing of European thought according to principles of "rationality," understandings of the nature of conflict shifted towards the struggle of reason as an ontological ground for combating exposure to the irrational $[13 ; 14$, p. $1-36 ; 15 ; 16$, p. 6-105; 17]. However, non-classical philosophy called into question the primacy and autonomy of the thinking consciousness, and hence the possibility of overcoming the irrational $[18 ; 19]$.

Taking diverse approaches, numerous $20^{\text {th }}$-century philosophical works have been dedicated to analysing the nature of conflict and the specifics of its concrete exposure. For example, existential thinkers locate the entity of conflict in experiencing co-existence with the Other [20-22]. In particular, Jean-Paul Sartre explores ways of establishing relationships with the Other in the light of the fundamental separateness of the I from the Other; however, he arrives at the tragic, unsolvable contradictions involved in constructing relations between people [23, p.301-558]. With regard to conflict on a social scale (for example, in his Overcoming of Metaphysics), Martin Heidegger explores the tendency of contemporary conflicts to push the Nietzschean concept of "will to power" to its limit, and, in its further functioning as "will to will," to convert everything into nothing [24]. 
The thinkers of the postmodern tendency develop this idea in their own manner, comprehending the phenomena of dominance of Structure, of human beings brought under control by Power, and of their subordination to Ideology, Discourse and Unconsciousness [25-28].

The plurality of ontological grounds within the contemporary situation prevents the possibility of establishing a single, reliable reference point when attempting to understand the nature of conflict. Is it caused by structures external to human consciousness or is it entirely conditioned by internal factors? Is it possible to know how to be and how to act within a conflict situation? Can the phenomenon of conflict ever be resolved entirely or should attempts be made to mitigate it taking a piecemeal approach? Answering similar questions, the philosophical directions of the "rational corps" stop in front of the cases of non-conscious conflict, since consciousness in itself cannot struggle with the non-conscious. For instance, psychologists show that "goal conflicts can occur outside of conscious awareness" [29, p.521]. Taking into account the irrational component of human beings, other philosophical approaches come to an understanding of conflict as the "conflict of identity" in light of the vagueness of both the I and the Other [30;31]. Eventually, the category of conflict itself becomes blurred and the reasons for the reproduction of conflict are allocated to forces beyond human control.

Despite the fact that much has been done to clarify the entity of conflict from different perspectives in the history of philosophical thought, little attention has been paid to consideration of the phenomenon of conflict through the fundamental ontological paradox of human existence. The present paper elucidates the nature of conflict by carrying out a phenomenological analysis of the initial paradox with which man deals in its existential situation. Inspired by the works of such Russian thinkers as Mikhail Bakhtin, Merab Mamardashvili, Vladimir Bibikhin and Elena Bakeeva, my approach unfolds a vision of the entity of conflict in its entirety by practising the particular methodology of acceptance of paradox as the non-uprootable given of Being. The productivity of this methodology is provided by the techniques of clarification of the sense of conflict by dipping into the existential situation of its participative experiencing. As a result, refraining the conflict becomes possible in a paradoxical way by means of working with the inner encounter of opposing sides, working on harmonisation of the self-state that takes its place also enriching the experiencing one by senses.

\section{Practical phenomenology and fundamental ontological paradox: Approaching the nature of conflict in its participative experience}

Generally, researchers choose a "reductionist" or "differentialist" strategy in approaching the nature of conflict. The first consists in the reduction of diverse conflict cases to one basic model. Hence, every conflict situation may be explained by imposing the basic model on the real situation as a scheme, which abstracts common "conflict features" from considered situations. Semantic analysis of "the ontology of conflict" [32] may serve as a shining example of the "reductionist" strategy. Also aimed at making the nature of conflict clear, the second strategy represents a differentiation between types of conflict, more precisely, between different means by which conflict emerges and develops as well as means for resolution or negotiation. Ultimately, every conflict situation is supposed to be unique; thus, each case is expected to deepen an understanding of the fundamental nature 
of conflict. Undoubtedly, a scientific approach is not conducive to an understanding of the uniqueness of every case; therefore, diverse classification techniques are typically applied to theorising the phenomenon of conflict. Although classification schemes combine both generalisation and individualisation, they are necessarily grounded on the difference as it is. Based on this assumption, numerous types of conflict have been distinguished due to the differences in terms of structure as well as the social roles and goals of various actors within a given conflict [33]. "Case study" variations are also frequently provided under the heading of "differentialist" methodology. To sum up, the "reductionist" strategy seems to create a universal picture of the phenomenon of conflict, allowing a scientific approach to be taken through generalisation. Along with this research strategy, the "differentialist" way turns out to be helpful in classifying unique features of diverse conflict situations. Both of the outlined strategies possess methodological potential, which surely finds its realisation in the theoretical representation of the phenomenon of conflict within various social and political disciplines.

Nevertheless, whether in combination or otherwise, these ways can hardly be relied upon when one practices being-in-conflict. Conflict types, models, schemes and strategies of its theoretical resolution as knowledge are undoubtedly helpful in providing scientific research in the field of conflict studies. Theoretical construction usage is surely to be approved in the light of solving research problems. Yet, despite its positive function in constructing a "world picture," by means of which man is orientated towards the world, the scientific methodology lacks instrumentation in experiencing the phenomenon of conflict "the hard way." Science as the "theory of the real" [34, p. 157] is actually useless for people who are experiencing real conflicts as their own problems within actual existential situations (see as well: [35]). Science often fails in producing answers to questions related to the meaning-of-life [36, p. 15; 37, p.6]. A claim such as "you might have known how to be / how to act" lacks productivity in the context of a real event, which happens with an individual in a unique way. The question "how to be?" cannot be resolved theoretically [38]; moreover, while this problem may seem to have a purely ethical dimension, it should also be considered at a deeper ontological level. Immanuel Kant taught that, in belonging to the sphere of "things-in-themselves" and being embodied by practical reason, the act remains unapproachable to science, with the speculative reason operating only in the world of "thing appearance" [39, p. 137-155]. With regard to conflict, one deals on an existential level not with its theoretical model, but with the real, unique situation, by which one is entirely seized. This aspect appears to be explained more clearly according to the early philosophy of Mikhail Bakhtin, who distinguishes "practical" and "theoretical" dimensions of human existence [38; 40, p. 278]. In Bakhtinian terms, the entirety of Being may be achieved only in a "practical" way through the participative experiencing of an event within one's own existentiality [38, p. 8]. When experienced participatively, conflict at any scale appears to be inseparable from the situation of inner struggle, which is practiced in terms of conflict with one's own self. The presence of this "inner" dimension conditioned the choice of existential-phenomenological methodology in the designated sense.

This paradox of theory and practice turns out to be sharpened within the certain conditions of the contemporary situation. As Martin Heidegger characterises these conditions, contemporaneity is revealed to be the planning-calculating provision of all things [24]. As features of contemporary science, abstraction, "a stand in objectness" and formalschematic re-presentation leave their stamp on contemporary man's way of thinking [34, 
p. 167; 41, p. 238, 253-254]. It is convenient to use the "planning-calculating" strategy in diverse cases; however, this strategy may be unsuitable for some situations, at least insofar as not all situations consist in manipulations carried out on and with "things." Including conflict, the situations of existential seizure appear to be "pure events," in terms of Gilles Deleuze [42, p. 146]. In an event, we deal with motion and dynamics; however, taking a scientific approach, we can only submit a construction of knowledge, i.e. only a fixing of an event as its picture. Even if we try to reproduce motion, illusion will be produced by applying the principle of changing pictures, points or "sections" of motion, as is realised in cinema (see as well: [43, p. 4]). In this way, we will find ourselves at the very heart of Zeno's classical paradoxes. If we try to perform an operation of "standing" the experience of conflict "in objectness," the real will escape; it will be passed over and, hence, will remain inaccessible (see as well: [34, p. 179]).

Further, in this paper, metaphorically speaking, paradox is used as an "instrument," with which the fundamental nature of conflict is considered from an ontological perspective. Numerous philosophers have understood the category of the paradoxical within Being as an "indicator" of an interesting sophisticated situation that requires investigation [44, p. 45-106; 45, p. 252-277; 46; 47; 42]. Each of these thinkers deals with the paradox in his own way, whether in showing it, describing it, experiencing it or playing it out. However, what is common to all of them is that the paradox marks the "place" of the ultimate problematic, through which we get an opportunity to deal directly with Being. This "dark place" turns out to be unclear due to the requirement for actual personal involvement in experiencing the paradox, which is rather difficult and unusual to deal with. If paradox were to be perceived as a simple contradiction, then logical analysis might easily have sublated it. Nevertheless, in cases of one's entire absorption by the sense of paradox and by its irrationality, reasoning and theorising lack explanatory power when faced with profound difficulties. Even the contemporary thinkers of the "rational corps" tend to notice that paradoxes should be learned for how to deal with excluding both ignorance and overcoming them. For instance, Ray Brassier, one of the famous speculative realists, claims that these difficulties cannot be simply circumvented by dispensing them with "dualisms such as those of meaning and being, and of knowing and feeling" [48, p. 291].

In regard to the existential-phenomenological investigation of the ontological paradox, such contemporary Russian thinkers as Merab Mamardashvili, Vladimir Bibikhin and Elena Bakeeva have undertaken much work in this area. Merab Mamardashvili practices the comprehension of the "impossible possibility" of Being through an existential analysis of experiencing the paradoxical nature of time [49], consciousness [50-52], the cultural phenomena and of the philosopher's calling [53; 54]. Despite Mamardashvili paying little attention to providing an ordered, systematic description of his method, his in-action approach proves to be productive in making the actual state of affairs clear. His philosophy helps the reader's vision to adapt itself to the essence of considered phenomena and resist giving way to the illusions that tend to appear around the most important "meaning-oflife" questions. Vladimir Bibikhin similarly aims at achieving clarity in terms of what is dealt with on the ontological level, i.e. at understanding the sense of the fundamental ultimate grounds of Being. In cases that involve dealing with a problem, he notices that an immediate resort to "activism" or "taking action" lacks productivity [55, p. 15-16, 20; 56; 57]. According to Bibikhin, actual sense is expected to be opened while hovering over the problem for quite some time by means of special thoughtful effort restraining ourselves 
from the drive to immediate decision-making. This passage allows for a consideration of the problems within the entirety of their paradoxical nature, which simultaneously lacks prepared solutions and permits the possibility of an actual understanding of the situation. As practiced by Mamardashvili and Bibikhin, this variant of the phenomenological approach enriches with experience and sense as well as teaching how to scrutinise every problem attentively.

Elena Bakeeva is also worth mentioning in the context of developing a methodology for dealing with paradoxes. In Accepting the Paradox, or an Effort of Humility, Bakeeva provides insight into the existential aspect of the contemporary situation in order to rethink such ontological categories as ground, sense, freedom, the I, the Other, love, God, reality, time, life and Being [58]. In this work, the thinker unfolds a participative experiencing of the paradoxical nature of any theoretical choice. The situation of pluralism makes a serious junction with one of the available points of view honestly impossible, as far as one's own ground and the entirety of Being prove to be unreachable in this case [59]. In order to accept this paradox, effort is required; it is only through such an effort that it becomes possible to comprehend the situation in a practical way and to explain it as productive-forthyself. For example, the paradox of the Other consists in the fact that "I can neither merge with the Other, nor do away with him" [58, p. 32]. Thus, this paradox is established in order to deal with the acceptance of the difference of ontological grounds of the I and the Other. This act of acceptance opens up the possibility of understanding man's particular position within Being, which establishes a proportionality between the need for one other in order to feel the "voltage difference" and harmless ontological co-existence due to the difference between our positions [58, p.33].

The fundamental ontological paradox reveals itself in this situation through the fact that the disinclination to confront the paradoxical nature of our own reason - or, more broadly, any human rule of thumb at the level of words - results in a turning away from sense. Man cannot live a fully-fledged life without sense; however, the path to sense goes by way of paradox, which may only be dealt with by the "creative" constituent of our mind. As has been thematised by, for example, Michel Foucault, Jacques Derrida, Gilles Deleuze and other poststructuralists $[25 ; 60 ; 42]$, the paradoxical nature of sense consists in the fact that, being the "expressible of proposition" [42, p. 19-22], it is itself contained neither in words, nor in things. Things and words are always guaranteed along with the other given symmetricities to be irreducible to each other; sense, on the other hand, is unguaranteed and unprepared, always requiring an effort of understanding without which it cannot exist. Pythagoreans and Aristotle dealt with similar pairs: in Being, we somehow deal simultaneously with right and left, male and female, even and odd, etc. Between these opposite extremes, something in the middle is absent and is unachievable by an admixture of them. These symmetric pairs then seem to be given on the ground of something "presymmetric" [55, p. 326]. This presymmetric One is known to be noncalculable, though it may be felt through and met in everything, as was discovered by Parmenides, who referred to it under "Being." When dealing with these kinds of pairs, we "hang" in-between them and feel that we are in a paradoxical situation, since the two opposite ends are given, but we deal with them through something referred to in terms of the "third."

In a paradoxical way, we have already had the sought-for, which represents a "thing" that tends to be intangible in the situation of the pursuit of the "third" and that tends to never be achieved on any of the two opposing sides of a willed theoretical choice. Such 
"escaping things" as sense, truth, time, God and Being escape neither due to our awkwardness, nor due to the absence of methods of apperceiving them. According to their nature, these "things" prove to be "behind our back" [61, p.23]; they themselves lighten for us our fundamental already-being-disunited into words and things, soul and body, good and evil. We can neither sublate nor refuse this duality by means of our will, nor can we skillfully choose one of the two opposing sides, since our disunity has been already established other than by means of our own act of will. While dealing with the paradox, neither refusal, nor a drive towards its immediate resolution, is productive. Conversely, learning to work with paradox is of great interest, since, along with its logical impossibility, we are provided with an opportunity to bear something out in the process of understanding - at least, to bear the unbearableness of the situation of the fundamental paradox, to which we are inevitably condemned as a consequence of our nature.

Thus, the paradox is perceived in such a way that, at the level of sense, we feel a kind of incompatibility, which detains our thought to run through its space evenly. Neither manipulation with meanings, nor any rearrangement of things in the world offers a result, since paradox cannot be considered as a simple contradiction. The paradox seizes with its fundamental strangeness, requiring special attention. When trying to deal with such things on the level of sense in the process of understanding, we obtain access to "that, by virtue of which" everything exists in a certain way. Nevertheless, it remains unapproachable as "something," eluding the grasp and continuing to escape, though we prove to be seized by Being, or by its fundamental paradox, or by the question about Being. Hence it becomes clear that the ontological paradox is solitary in spite of our dealing with it in different situations, on the material of diverse content and in various modifications. However, the understanding of the singularity of the paradox of our Being does not make a solution easier, since an experiencing of the paradox occurs every time in a unique way and it must take place anew every time, i.e. it must take place on the existential level. The singularity of the paradox may serve rather as an instrument of the elimination of the fundamental fear of non-being, which we risk falling into after the awareness of incertitude of any human situation within Being [62]. Though each person experiences paradoxicality in his or her own individual way, the positive moment consists in a universal form of the ontological paradox. Consequently, others also deal with it: that is why, even being separate within his or her own situation, each person is not alone within Being. As the "propaedeutic," such moments appear to be productive and helpful in setting oneself up for an "adaptation" of the own vision. Due to this purified vision, we achieve in its entirety an "impossible possibility" of understanding the situation, with which we face.

In accordance with the described methodology, in order to understand what we deal with in a conflict situation and to grasp the ontological sense of the phenomenon of conflict, it is necessary to embody a practical experience of experiencing of the paradoxical nature of conflict. Practicing this methodology is sure to be rather difficult due to the risk of experiencing a kind of injury while dealing with the "inner dimension" of the paradox; fortunately, other ways exist, aimed at approaching the entity of conflict. Nevertheless, due to the decision of taking a leap in the absolute uncertainty and strangeness of the paradox, something new may be born from this existential-phenomenological investigation; this alternative vision may also be helpful in understanding the new planes of the phenomenon of conflict. Though this method is paradoxical in itself, it is one of the ways of approaching the phenomenon of conflict. 
However, in our case, being existentially weighted, the paradox is deeper. Even if we were able to identify the type of conflict within which we find ourselves, and even if we knew about the possible ways of its development and of its resolution, we would ourselves have to act and make choices at our own risk. As Immanuel Kant warned, knowledge proves to be useless in a situation within which an act is required. Responsibility for the real situation appears to be maximal and ultimate; here we cannot allow ourselves to make a mistake. It is fearful for us to carry out experiments with our own lives "in vivo" as it was "in vitro." In this situation, we should not test the capability of all alternatives since this game may result in such consequences as quarrelling with others or even, in some cases, fatality. Calculating the probability of an event's development will always leave the possibility for the most negative conclusion and thus only strengthen our existential anxiety. And, even if this kind of existential situation is experienced by someone who is a scientist, researcher - i.e. calculative according to their calling - and, hence, if they cannot deal with the situation in any other way except calculation and rational analysis in light of their freedom; nevertheless, the conflict situation remains a noncalculable moment of faith or resolute desire.

Resolution is an event, an act, which is noncalculable in of itself. Either it happens in its entirety, like a flash, illuminating everything around it, or resolute desire does not result and a person feels at a loss among aporias. Neither force, nor calculation, proves to be helpful in this situation. Then, how does one get out of this paradox? Is resolute desire a path, an exit? Yes and no. Yes, it is, since the reality of one's own act is impossible without it. And no, it is not, since it cannot be created as desired, i.e. it is impossible to create a strategy of reaching the moment of resolute desire. However, are we doing anything else except finding a solution in order to get out of the situation of the real conflict, which has seized us? Actually, the aim of this research consists, first of all, not in resolving conflict, but in understanding its entity. It is important to restrain oneself from striving to solve conflict immediately and, instead, to try to hover over the experiencing of conflict in order to get an opportunity to touch its fundamental nature. For this reason, the difference between the practical experience of conflict of any scale and theorising about it is emphasised, since practice allows the entity of conflict to be seen in its entirety, and, among other things, manages it in a paradoxical way.

\section{Paradox of I and the Other within the context of "good" and "evil" as a root of any conflict}

Thus, the moment we attempt to get closer to the conflict through the experiencee of being-seized by this situation, we encounter repulsion. We have been thrown into conflict resolution; it is bound to happen due to the unbearableness of the situation of conflict. As soon as we begin to deal with the possible consequences, our finitude appears on the horizon. Finitude "switches on" an existential anxiety in us and this anxiety is unbearable. And, reacting against the unbearableness of the thought concerning finitude, the mechanism turns on automatically, causing a drive to solve, to overcome - or, as another variant of immediate reaction, to ignore conflict. In this way, an immediate necessity arises to perform any reaction certainly, resolving the situation in order to dispose of the painful anxiety. It is at this point that we decide with certainty who is good and who is bad, who is just and who is unjust. We are sure insofar as it seems that there is nothing to question - everything is already clear. Here it is appropriate to recall the remarkable dialogue 
between Socrates and Alcibiades [7]. Only enmity, force and war seem to be efficient in proving our justice for those who misunderstand, for whom our resolute desire remains unobvious. Somehow all at once, I, my party, my country, my side prove to be good and just; we do not know why, but we are always already certain about such states of affairs. Words appear to be already helpless in providing an alternative explanation, since in this situation we have already missed the moment of that decision about good and evil, just and unjust. From whence have we already obtained knowledge about such things?

Here it becomes dark, however positive is the fact that we have noticed it and have stopped ourselves in order to pay attention to this moment. In Aristotle's terms, man appears to be an ethical "animal" or a political one [63, p.9-11]. For us, man, the question is always about good and evil, just and unjust and is always "painted" in some "colours." Due to our existential nature, we seem to be incapable of avoiding the automatic differentiation of everything into the categories of good and evil. Already present for us in our childhood, our finitude seems to compel us to differ and distinguish. Appearing thus on the horizon, the limitation of our existence turns out to compel us to choose only what is fit. However, not everything is sure to be fit, since a lifetime cannot be wasted on considering all alternatives; consequently, in order to choose only what is good-for-us from everything existing, the ability to see good and evil simultaneously seems to be necessary. Returning to our question about the source of our knowledge about good and evil, justice and injustice in and of themselves, we should scrutinise the situation more attentively. We know about it precisely from nowhere. Finally, Alcibiades declares himself an "ignorant" of just and unjust; Socrates summarizes: "Consider; I believe you will fail to find such a time [when you hesitated to decide immediately about just and unjust]" [7, p. 123]. Should we find such a time or should we seek out of time? The paradox looms large here. Analysing the question about the origin of war (which represents a variant of conflict, its synonym in a broad sense), Vladimir Bibikhin proposes the following passage [55, p. 192]:

People wage war not for things in existence. A nation would not rise to a war aiming at driving the neighbouring nation back by several kilometres or at teaching them the niceties of table manners. A nation-wide mobilisation is called for insofar as the neighbouring nation acted unjustly, proved to be evil, vicious and has a wrong false faith... Man lights up, having a burning desire, only from lacking, non-existent things. I will plunder and kill not because I have to eat something and to watch television and video, using the corresponding devices, but because I lack peace inside of me.

Hence, in the case of waging war, or more widely, in the case of participating in conflict, we are driven by this decision, which we have automatically adopted in a hurry, about good and evil, innocent and guilty, just and unjust. We are ruled by an implicit assurance; however, this automatic vein appears to be a breakdown. Concerning good and evil, neither knowledge, nor decision-making, is initial. The initial consists in our fundamental ignorance, misunderstanding and incapability to resolve the situation. Firstly, if everything is clear, a thought is absent and a motion is impossible. Only misunderstanding provides an opportunity for understanding to appear. Secondly, any awkward situation turns out to be a marking of the paradox, and the paradox is a marking of Being, of the real, of sense $[45$, p. 252-277; 42]. We are afraid to take a leap into the darkness of the paradox due to the fundamental uncertainty of what is waiting for us inside the paradox. Thirdly, arising from the paradox, fundamental incertitude awakes fear in us, initialising a drive to recoil quickly and run away in order to escape the state of total uncertainty. Indeed, as numerous 
thinkers notice, people decide to take a leap into the paradox perhaps "out of the bare necessities of life," with despair reaching its bottom. The logical constituent of our thinking will never accept the paradox, since the paradox is perceived by it as an annoying absurdity, which should be eliminated or overcome. Nevertheless, the absurd is the human experience of being-seized by love, faith, despair and sorrow. Hence, as Bibikhin argues, a war occurs only around "non-existent things" [55, p. 192], even, more precisely, around both "existent and non-existent" things, which are experienced by one our constituent and are rejected by the other one. We ourselves appear to be walking paradoxes! And, first of all, the paradox opens in that I seem to be the Other for myself as far as, being simultaneously experiencing something and thinking of its sense, I do not coincide with myself. We turn out to be places of unfolding of the fundamental paradox, from out of which its possible content variants spout, being perceived as contradictions, aporias, incompatibilities, etc. The unbearableness of the paradox contains two dimensions: we cannot exclude it from the inside of ourselves, but we also cannot bear it. It is precisely due to this double-faced unbearableness that we "lack peace inside" [55, p. 192] meaning we lack the very unity; each of us deals, first of all, with "inner war", the impossibility of avoiding which compels us to convey the war inside-to-out, i.e. into the surrounding reality.

The energy of the unresolved inner conflict of me and I as the inner Other for myself proves to be easily redirected outside and to be transmuted into various types of confrontation with any outer Other, whether they are a concrete person, a group, a structure, a party, a nation, etc. Diverse structures use it and seem to have been using it at all times, changing only the content of appeals and the transmitting media. As Georg Simmel notices, the "average man" may be characterised by the incredibly easy suggestibility of a hostile attitude of mind [64]. It is more difficult to inspire a favour and trust to the Other, than to inspire a negative opinion about them, which forms itself almost automatically. If imagination becomes aware of any possible unfairness or injustice concerning the Other, it will immediately complete the formation of an image justifying hostility. This fact may be also due to the paradoxical position of man within Being. As Mikhail Bakhtin writes, every I is sure to be provided with "the uniqueness and irreplaceability of [their] place in the world" $[65$, p. 23]. This means that one-and-only-one point of view is given to every I within Being; nobody can actually occupy the Other's place. Consequently, human finitude turns out to consist not only in the limitedness of our lifetime, but also in our topological bordering with the Others. People tend to be rather sensitive to such a limited position within Being, perceiving it as a constant lack of wholeness. Due to this, desire seems to appear in order to overcome the temporariness of human existence, achieving immortality in this or that way. Frequently this desire takes the form of will to overcome the topological, pointlike character of one's own Being, tending either to receive the possibilities of the Others into itself, or to liquidate them.

Nevertheless, the consideration of all possibilities should put us on guard by its infinitude. Man categorically cannot realise all the other possibilities within his only life; each can realise just his own way of being within his own existence. In the Republic, Plato illustrates that a vast number of conflicts within society occur due to some people ignoring their own way of being, which is all that is actually accessible [8 p. 97-125]. Moreover, the only criterion against the entirety, self-realisation and happiness consists in following one's own. Insofar as public opinion tells us something different about happiness, numerous people appear to be easily swayed by it and inattentive to themselves; being busy with 
a "money spinner" instead of their own calling. In this case, neither power, nor prosperity satisfies; one begins to seize everything around due to continuing to be unseized by the own way of being. Finally, suffering from the lack of the entirety of Being, people get offended and automatically vent their anger on the Other. However, this fact frequently is not considered, since one is sure about the other people - as if it is the others who are taking away a part of his or her own possible realisations. The acceptance of the Other occurs completely and absolutely only within our own self-supportability and self-actualisation and comes marked by the state of love as readiness for acceptance and understanding of everything and everyone as they are. When we realise our own way of being, which fills our life with sense and makes us happy, we become fulfilled in an intensive way, i.e. without seizure of the other places. In this situation, the Other obviously cannot do harm to one's self-actualisation, since the Other is who realises another possibility. Nevertheless, people often continue to convey their inner conflict inside-to-out, trying to involve as many others as possible in it. Such people tend to think that this process provides them with ascendancy over others. However, as far as this entirety remains unreachable by means of considering alternatives, these people remain unhappy. Despite the anger these people provoke in us, trying to control us and interrupting the process of our self-realisation, they actually need just to be pitiful to them.

Naturally, nobody is guaranteed against involvement in external conflicts, into which we appear to be provoked everyday by others, including mass media. However, featuring the free man, spontaneity and natural irrational unpredictability work reliably against the planning-calculating attitude of these structures towards everyone. People who lack peace inside-to-out, try to involve us in the conflict in order to make us play their game, to be afraid of them, break down and subordinate ourselves to them. Although no prepared formula can be given on how to act in such situations, what is helpful is to develop an ability to hesitate, to mark time, to restrain our own temper and hold our own reactivity in check. A helpful approach is to let the situation go and to give oneself up to it; and if we at the same time try to avoid "taking action," dwelling inside the ultimate readiness to meet the situation being unprepared and comprehending it in "here-and-now," when it comes, the path will show itself. The situation will indicate the needed path and the answer sought for. Here we deal neither with being ahead of the provoking person, nor with punishing them for injustice. Embodying a vindicatory punishment is sure to be out of our control; moreover, this impulse has already been embodied within the wretched existence of such a person. As for us, it is simply important to remain being ourselves- human in such situations, whether they occur in war or in times of peace, at work, in family or within public policy.

Nevertheless, self-realisation according to one's own way of being cannot serve as a panacea for all woes; moreover, acceptance of one's own uniqueness appears neither to be a way of eliminating conflicts, nor something that divides us into "good" and "bad." Obviously, both good and evil are equally inherent in everyone; regardless of "knowing thyself," everyone is potentially able both to make malicious mischief and to bonify. Moreover, we cannot decide with our will "to become an advocate of good and justice starting from today." Neither "advocates of good and justice," nor anyone else among people seem to know - or even are able to know - what will produce good and justice within their acts. Performing the honest complete acceptance of our finitude, our limitedness, our paradoxical nature, we accept in this act the whole world, including the "splitted" I and the unreachable Other. It appears to be very important: an activism of 
"taking action" is certain to be the reverse side of genuine acceptance; non-acceptance of the world, of the Other and of one's given position within Being displays itself in hurrying to "take action." When we reject everything as it truly exists, we bear this rejection externally, trying to control the Others, to reorganise Nature beyond measure and to create someone planned and other from the ourselves. What is obvious is the destructiveness of the refusal to Being in acceptance of the all as it is: both the world and man in ruin. These moments are thematised in detail in the philosophy of Erich Fromm, who pays special attention to the fundamental problems of co-existence with Others [66; 67]. Hence, without the complete acceptance of the Other and without love towards them it proves to be almost impossible to avoid bearing the inner conflict inside-to-out. In this act, we deal with inner work with the entity of any conflict, which has seized us, becoming, consequently, our inner one.

\section{Social dimension of unresolved inner conflict and the paradoxical way of solution}

In the light of the discussed above idea of easy suggestion of the hostile attitude of mind, the following moments on the manipulation of public conscience should be considered in the context of acceptance and non-acceptance of the fundamental ontological paradox and readiness and unreadiness to work with it. The constructing of a positive image of, for instance, a government or a native country, may be achieved automatically by representing the "opposite" structure in negative colours. It seems to be difficult to compel someone to believe that "our" proves to be undoubtedly good, since its numerous problems are plain to see. On the other hand, it is much easier to create an illusion around the negativisation of the "other side," which becomes perceived as an opposing one to the "our." Then it tends to automatically follow to the "average man" that if "bad" belongs to the quasi-opposing side, "good" is sure to be located thereafter on their own side. Due to our ethical nature, we are certain to distinguish between good and evil; nevertheless, few people reflect on the fact that the borderline between good and evil should be drawn in oneself and should be constantly reconsidered. Insofar as it is pleasant to identify oneself with the "good" side, it turns out to be simpler to draw the borderline externally. During the $20^{\text {th }}$ century, mass media appears to have largely assumed the function of forming the world picture in human consciousness on this basis, taking this function away from science. Returning to Kant, science cannot and should not form judgements concerning ethical aspects. Consequently, science may lay claim only to an incomplete world picture, which lacks answers to questions about good and evil. Then the "average man" loses faith in the strength and explanatory power of the scientific world picture, and especially with the complexity, mathematisation and abstractedness of what contemporary science contributes. Accordingly, this niche has been occupied mainly by mass media in the contemporary era. Although the picture they form turns out to be fragmentary and fleeting, nevertheless, it is apparently easy to understand and it appears to provide some reference points on questions of good and evil.

In this context, the following rationalisation also seems to be rather productive. Largescale warfare and conflicts occur at moments critical for the mass human consciousness. These large-scale wars tend to mark the so-called "end of an era," i.e. historical periods change from one to another, forming a joining point that coincides with the experienced 
multilateral armed conflict. During periods of significant changes in world-view, it becomes literally unbearable to lose the former grounds, which had seemed so stable. When the former principles stop working and producing sense within fast changing conditions, searching for new reference points is a painful process. As far as the complete incertitude of one's existence displays itself clearly, it becomes necessary to tackle the problem of fundamentally rethinking everything, starting "from scratch." This act proves to be extremely complicated and risky; therefore, being unready for this, numerous people hurry to resolve the unbearable inner tension that is felt as "hanging over the abyss." Various structures around are always here to "help," promising the Good, an easy way and a prepared solution; however, these structures are actually aimed at possessing and controlling these people. Naturally, one agrees to the offered outer substructures, since one does not desire to meet the situation of the absence of a reliable ground with courage and self-sustainability. On the face of it, these substructures appear to be rather harmless, as with, for example, contemporary advertising. However, phantasms and illusions generated within us prove to be dangerous due to their replacement of our own thinking in our consciousness. They offer us "protection" from the gaping source of problems, which is recursively enrooted in our lack of readiness to deal with it using our own resources. In this way, suspiciousness to any other emerges naturally, followed by an explicit enmity and desire to liquidate the other positions, which involves fighting those structures' corner and even laying down one's own life for it. In this way, the Roman Empire seemed to collapse in classical antiquity. In this way, the Medieval Crusades took their place. In this way, the Renaissance with its Protestant Reformation and Counter-Reformation culminated in the Thirty Years' War. In this way, the Enlightenment failed to save from the Napoleonic Wars. Lasting for already more than two centuries and continuing to deepen, the crisis of European rationality continues to "thrill" the world with the global conflicts in exactly the same way. The difference in the contemporary situation consists perhaps just in the scale and sophistication of the forms and ways of waging a never-ending war: weapons, ideology, information, economic pressure, proxy warfare, space technological race, etc.

Undoubtedly, not everyone is easily swayed by mass media, since the "reality" presented by mass media turns out to be absurd and contradictory, therefore to eventually lead precisely nowhere. When we hesitate and feel the lack of resolute desire, beginning to doubt in the fitness of such a picture of reality, we have an opportunity to hover over this situation of the insolvability of what comprises a "good" reference point. This is also certain to be the case of the conflict situations, which are infixed into us and surround us: Which religion provides a reliable ground for my acts? Which nation is right in the civil war? Which party should I choose? Who is just among my colleagues? Are my relatives and friends right in this or that question? Supposedly, without being in a hurry to resolve the conflict, the attentive scrutinising is expected to allow us a resolute desire of another kind. This alternative resolute desire is to declare ourselves to be ignorant of what "actually" comprises good and evil. From whence could this knowledge be made available to us finite limited creatures? However, here we are not dealing with the hopeless existential situation; on the contrary, we are dealing with the moment, within which we get an only chance to act in a productive way and to understand something for ourselves.

Thus, representing unreadiness to stop thyself when dealing with the ontological paradox within the own situation, the frequent behaviour of the "average man" seems to 
explain a slide into non-acceptance, hostility and war. We tend to bear conflict insideto-out due to the unbearableness of the conflict with oneself, which, in its turn, appears to be the conflict of fundamental duality of the human nature. The inner conflict may therefore represent the conflict of inability to deal with our paradoxical nature, which displays itself to us as a quasi-confrontation of the own and the other, of the whole and the fragmentary, of entirety and lack, of freedom and necessity, etc. It may seem that Good is located only on one of these two sides. Nevertheless, while following through the experience of dealing with the fundamental ontological paradox in a phenomenological manner, we find that the Good is located prior to this difference, being, moreover, provided not by us. Undoubtedly, participating in the outer conflict appears to be just one among other cases of escaping from the unbearableness of the inner; despairing of the encounter with their own paradoxical nature, numerous people drive themselves to mental disorder, drug or alcohol use. Then, can we somehow change the situation for the better at all? Oh, would that we knew where the better was! We are not Gods - we lack this knowledge. Then, what shall we do within this paradoxical situation? The question turns out to be incorrect, as Heidegger explains: "Before considering the question that is seemingly always the most immediate one and the only urgent one, What shall we do? we ponder this: How must we think?" [68, p. 40]. Accordingly, it is more productive if we restrain ourselves from the activism of "taking action," at least until we understand what and how we are dealing with. We may think in some other way in order to enter a state of harmony with this comprehensive strangeness, including the strangeness of such a quantity of the repetitions of an undigested experience of war in the history of humankind. It seems to be more productive to accept the fundamental paradox, stopping in front of it with the courage of humility. Being placed into human beings not by the human beings themselves, the enigma of the strangeness of the human nature must be understood as non-uprootable and unresolvable by the human beings. However, we may also abstain from the contemporary approach of dealing with the world instead of dealing with ourselves and with the opened-for-man paradox.

Within our own existential situation, the effort of acceptance of the fundamental ontological paradox opens a paradoxical possibility for our whole Being, for the entirety of our own belonging to Being and for wholeness as fulfilment. Nevertheless, as has been shown, acceptance of the paradox comes only through tremendous effort. The state of acceptance may also be noticed to be very difficult to stay in; due to our nature, we fall out of our own place of "being-seized" by Being. However, the productivity of this state is obvious; hence, the will to return to this state also appears to be natural. If any actual ethics are possible for man, then it turns out to be an ethics of effort of acceptance, which here coincides with ontology. Good - and the entirety of Being as Good - may be opened due to the effort of acceptance of all and being in agreement with everything. We appear to be able to come into such a state of the own by means of fine tuning of oneself in an attempt to accept everything as a substitute for "taking action." Consequently, by marking time for a while and restraining ourselves from immediate activism within the situation of conflict, it appears that the conflict of any scale consists in our own stabbing by the non-acceptance of the state of affairs, including our own position. Nevertheless, if we scrutinise this fact attentively, it may be noticed that, prior to any decision taken by ourselves, our own position as the one-and-only good has already been provided within Being itself. However, this also means that we lack a guarantee of 
having good and justice on our side without an effort; on the contrary, as Kierkegaard repeatedly claims, "we are always in the wrong" [69, p.595-609]. In order to understand productively, it proves to be sufficient to practice the fine tuning of oneself to the vision of the fact that we are provided with everything necessary, even despite the lack of knowledge about good and evil, justice and injustice, truth and falsity. We discover the absence of incompleteness and, ultimately, non-being in the world; other modes, states and ways of being are likely to exist and all of them appear to be existent within Being in such a way as is necessary. In this context, one of the variations of the fusion of ethics and ontology may have been represented in the Leibnizian idea of this actual universe as the most perfect among all possible ones [70].

As can be seen from the above, while, on the face of it, the existential effort of acceptance seems to change nothing in any "outer" state of affairs; paradoxically, it actually changes everything, turning "minus" into "plus" in our "inner" dimension. We remain in the same place anyway, since the effort aimed at taking us out of this place is impossible and hence unproductive. Nevertheless, through the acceptance of everything in its entirety including the duality of "good" and "bad," "I" and "Other," "light" and "dark," etc., we return to the own, including the acceptance of this own as inevitable. What do we need this for? Only through the own, only finding oneself within the own place and only with the courageous acceptance of the own finitude, limitedness and paradoxical nature, we become able to produce sense, to understand, to be attentive to everything around us - and to act. Consequently, the fine-tuning of oneself in terms of the harmonisation of self-state turns out to be what is ultimately common to humanity, i.e. what makes a person who he or she actually is. Then, may we dream about the elimination of all conflicts? Unfortunately, no, since the paradox, which includes the mode of conflict, seems to be inevitable for the human nature. Conflicts will continue to take place independently of our effort of acceptance; nevertheless, in the present work, I have attempted to develop an approach towards an understanding of the fundamental nature of conflict in the light of this effort. This approach consists in the practicing of an actual existential-phenomenological work with and on oneself, which I have tried to demonstrate within this research. These methodological results are in agreement with those achieved by such Russian phenomenologists as M. Bakhtin, M. Mamardashvili, V. Bibikhin and E. Bakeeva, whose tradition I carry on in an attitude of hope and respect.

\section{Conclusion}

In the present paper, I have followed a serious - and even, as may be argued, rather overambitious - aim that consists in arriving at an understanding of the fundamental nature of conflict. However, whether successful or not, philosophical research following such an aim should be continued. The search for a unified grounding of the phenomenon of conflict may provide insights both into new aspects of "outer" conflict, which may be valuable for science, as well as into an understanding of "inner" conflict for the individual person who experiences this phenomenon within their own existential situation. In light of the designated perspectives, a variation of the existential-phenomenological approach has been applied as a special work with the ontological paradox. Faced within the state of existential experience in its diverse variants, the paradox of Being is experienced as unbearable; hence, it is frequently "born out" in the form of conflict, engendering latent or 
patently hostile attitudes towards the Other. In this research, I have developed a methodology of adaptation to the phenomenon of conflict infixed into the human condition; this methodology makes it possible to work with the situation of an "inner war," refraining its bearing inside-to-out and a productive "recycling" energy of unsolved and actually nonsolvable conflict into understanding the sense of the ontological paradox. In this way, harmonisation of self-state takes place in order to fine-tune oneself to the actual vision of the situation through and beyond schemes and illusions; in turn, this proves to be helpful in creating forces resistant to the destructive nature of conflict. Despite the introduced techniques for dealing with a conflict situation, this methodology cannot be understood as universal in the sense of its inability to be applied "mechanically." Harmonisation of selfstate must - and only may — be embodied by means of participative experiencing. This means that its reproduction appears to be possible only by means of being embodied each time anew, "from scratch" and in the unique way in any single case. Nevertheless, within the form of each concrete act, the following "steps" may be distinguished as follows. First, an encounter with the ontological paradox should occur in any of its content-burdened variants. Then an effort should be undertaken in order to accept the seized situation in its entirety and wholeness and, hence, in its inevitably paradoxical nature. As the following step, a rigorous phenomenological investigation of the paradox should take place, aimed at an understanding of the sense of what the experiencing one is dealing with. Finally, harmonisation of self-state should be practiced by means of adaptation to the paradox and its simultaneous fitting in the function of an "instrument" for purifying one's own vision. Therefore, work with the self-state proved to be a work on fitting; it consists in the dynamics of fine tuning oneself to the productive vision of how everything is, which shows the "exit" as a path, or as the "lighting of Being" [71, p. 89]. Undoubtedly, this methodology has its own disadvantages and limitations and requires further elucidation. This paradoxical methodology is also sure to be unsuited to a theoretical approach to problem solving aimed at revealing the development of trends of diverse conflicts; fortunately, numerous contemporary scientists are engaged exactly in the production of these kinds of theories. In terms of the author's interest, future research will focus on further elaborating the methodology for dealing with the ontological paradox presented in this article. This "inner" work is expected to be productive in diverse situations due to its methodological potential, which may be embodied as a means of harmonisation of self-state and a way of fine tuning actual understanding in the face of the dispersing and destructive tendencies of contemporaneity.

\section{Acknowledgements}

The author thanks Dr. Popova for valuable advice and assistance in improving the structure, language and style of this article. The author also thanks Mr. Beavitt for proofreading and comments, which helped to improve the manuscript.

\section{References}

1. Jenkins, R. (2000), “The Limits of Identity: Ethnicity, Conflict, and Politics”, Sheffield Online Papers in Social Research, no. 2, available at: https://www.sheffield.ac.uk/polopoly_fs/1.71447!/file/2jenkins.pdf (accessed: 06.08.2018).

2. Feldman, D. L. (2003), Conflict Diamonds, International Trade Regulation, and the Nature of Law, available at: http://scholarship.law.upenn.edu/jil/vol24/iss4/1 (accessed: 15.08.2016). 
3. Oduro-Frimpong, J. (2007), "Semiotic silence: Its use as a conflictmanagement strategy in intimate relationships”, Semiotica, vol. 167, pp. 283-308.

4. Mitchel, A. (2009), "Conflict-in-Transformation: Ethics, Phenomenology and the Critique of the 'Liberalising' Peace”, International Peacekeeping. Special Issue: Liberal Peacebuilding Reconstructed, vol. 16, no. 5, pp. 667-684.

5. Aleinikov, A. V., Gazimagomedov, G. G. and Strebkov, A. I. (2017), "Surgery' and 'Therapy' of Corruption: The Conflict Studies Dimension", Vestnik of Saint-Petersburg University. Philosophy and Conflict studies, vol. 33, no. 4, pp. 528-540. (In Russian). DOI: https://doi.org/ 10.21638/11701/spbu17.2017.411

6. Thucydides (1956), History of the Peloponnesian War in Four Volumes, vol. I, William Heinemann Publ., London.

7. Plato (1964), "First Alcibiades", Charmides, Alcibiades I and II, Hipparchus, The Lovers, Theages, Minos, Epinomis, William Heinemann Publ., London, pp. 98-223.

8. Plato (1991), Republic, $2^{\text {nd }}$ ed., Basic Books: A Division of Harper Collins Publishers.

9. Plato (1961), Laws, in 2 vols., William Heinemann Publ., London.

10. St. Augustine (1997), The Confessions, New City Press Publ., New York.

11. Abelard, P. (1995), "Ethics or 'Know Yourself”, Ethical Writings, Hackett Publishing Company, Indianapolis, Cambridge, pp. 1-58.

12. Aquinas, T. (1955-1957), “Book II: Creation”, Summa contra Gentiles, Hanover House, New York.

13. Bacon, F. (2000), The New Organon, Cambridge University Press, Cambridge.

14. Descartes, R. (1991), Principles of Philosophy, Kluwer Academic Publishers, Dordrecht, Boston, London. bridge.

15. Descartes, R. (1989), The Passions of the Soul, Hackett Publishing Company, Indianapolis, Cam-

16. Hobbes, T. (1994), Leviathan: with selected variants of the Latin edition of 1668, Hackett Publishing Company, Indianapolis.

17. Locke, J. (1836), An Essay Concerning Human Understanding, T. Tegg and Son Publ., London, UK.

18. Nietzsche, F. (2002), Beyond Good and Evil: Prelude to a Philosophy of the Future, Cambridge University Press, New York.

19. Freud, S. (1989), New Introductory Lectures on Psycho-Analysis, Norton \& Company Publ., London, New York.

20. Marcel, G. (1999), Essai de philosophie concrete, Gallimard Publ., Paris.

21. Merleau-Ponty, M. (2012), Phenomenology of Perception, Routledge Publ., New York.

22. Levinas, E. (1987), Time and the Other, Duquesne University Press, Pittsburgh.

23. Sartre, J.-P. (1992), Being and Nothingness: A Phenomenological Essay on Ontology, Washington Square Press, New York.

24. Heidegger, M. (2003), "Overcoming of Metaphysics", The End of Philosophy, The University of Chicago Press, Chicago, USA, pp. 84-111.

25. Foucault, M. (1966/2002), The Order Of Things: An Archaeology of the Human Sciences, Routledge Publ., London, New York.

26. Deleuze, G., Guattari, F. (2000), Anti-Oedipus. Capitalism and Schizophrenia, University of Minnesota Press, Minneapolis.

27. Žižek, S. (2008), The Sublime Object of Ideology, Verso Publ., London, New York.

28. Badiou, A. (2006), Bodies, Languages, Truth, available at: http://www.lacan.com/badbodies.htm (accessed: 02.09.2016).

29. Kleiman, T. and Hassin, R. R. (2011), "Non-conscious Goal Conflicts", Journal of Experimental Social Psychology, vol. 47, pp. 521-532.

30. Nancy, J.-L. (2000), Being Singular Plural, Stanford University Press, Stanford.

31. Rothman, J. (1997), Resolving Identity-Based Conflict: In Nations, Organisations, and Communities, Jossey-Bass Publishers, San Francisco.

32. Greco Morasso, S. (2008), “The ontology of Conflict”, Pragmatics \& Cognition, vol. 16, no. 3, pp. 540567.

33. Galtung, J. (1973), Theories of Conflict, University of Hawai'i Press, Honolulu.

34. Heidegger, M. (1977), "Science and Reflection", The Question Concerning Technology and Other Essays, Garland Publishing Inc., New York, London, pp. 155-182.

35. Sartre, J.-P. (2005), Existentialism is a Humanism, available at: https://www.marxists.org/reference/ archive/sartre/works/exist/sartre.htm (accessed: 06.08.2018).

36. Ortega y Gasset, J. (1962), History as a System and Other Essays Toward a Philosophy of History, Norton \& Company Publ., New York, London. 
37. Husserl, E. (1970), The Crisis of European Sciences and Transcendental Phenomenology, Northwestern University Press, Evanston.

38. Bakhtin, M. M. (1999), Toward a Philosophy of the Act, University of Texas Press, Austin.

39. Kant, I. (2002), Critique of Practical Reason, Hackett Publishing Company, Indianapolis, Cambridge.

40. Pape, C. (2016), "Husserl, Bakhtin, and the Other I. Or: Mikhail M. Bakhtin - a Husserlian?", Horizon. Studies in Phenomenology, vol. 5, no. 2, pp. 271-289.

41. Popova, N., Moiseenko, Ya., and Beavitt, T. (2017), "Conformity in Modern science: An Engine of Societal Transformation?”, Changing Societies \& Personalities, vol. 1, no. 3, pp. 237-258. DOI: http://dx.doi. org/10.15826/csp.2017.1.3.017

42. Deleuze, G. (1990), The Logic Of Sense, The Athlone Press, London.

43. Deleuze, G. (1997), Cinema 1: The Movement-Image, University of Minnesota Press, Minneapolis.

44. Plato (1931), "Parmenides", Dialogues of Plato in Five Volumes, vol. IV, Oxford University Press, London, pp. 1-106.

45. Aristotle (1857), Metaphysics, Henry G. Bohn Publ., London, UK.

46. Nicholas of Cusa (2001), "On Not-other", Complete philosophical and theological treatises of Nicholas of Cusa, vol. 2, A. J. Banning Press, Minneapolis, pp. 1108-1166.

47. Kierkegaard, S. (2006), Fear and Trembling, Cambridge University Press, Cambridge.

48. Brassier, R. (2011), "Concepts, Objects, Gems", Theory after 'Theory', Routledge Publ., London, New York, pp. 278-292.

49. Mamardashvili, M. K. (1995), Lections on Proust: Psychological Topology of the Way, Ad Marginem Publ., Moscow. (In Russian).

50. Mamardashvili, M.K. and Piatigorskii, A.M. (1997), Symbol and Consciousness: Metaphysical Mediations on Consciousness, Symbolics and Language, Shkola "Iazyki russkoi kul'tury" Publ., Moscow. (In Russian).

51. Maikov, V. V. (1989), "Consciousness is Like a Paradox, to Which One Cannot Become Habituated + Interview with Merab Konstantinovich Mamardashvili”, Voprosy Filosofii, vol. 7, pp. 112-118.

52. Mamardashvili, M.K. (2010), “The Problem of Consciousness and the Philosopher's Calling”, Russian Studies in Philosophy, vol. 49, is. 2, pp. 8-27.

53. Mamardashvili, M. K. (1992), How I Understand Philosophy, $2^{\text {nd }}$ ed., Progress Publ., Moscow. (In Russian).

54. Dolzhenko, O. (2010), "How I Understand Philosophy: A Conversation with Merab Mamardashvili", Russian Studies in Philosophy, vol. 49, is. 1, pp. 7-19. sian).

55. Bibikhin, V.V. (2012), Property: The Philosophy of one's own, Nauka Publ., Saint Petersburg. (In Rus-

56. Bibikhin, V. V. (1997), "One’s Own, Private Property + Economic, Ethics and Social Aspects of Market Economy in Present-day Russia", Voprosy Filosofii, vol. 2, pp. 71-81.

57. Bibikhin, V.V. (1998), “One's Own, Proper. What is Property in its Essence?”, Social Market Economy: Theory and Ethics of the Economic Order, pp. 115-127.

58. Bakeeva, E. V. (2009), To Accept the Paradox, or an Effort of Humility, Ural State University Press, Ekaterinburg. (In Russian).

59. Bakeeva, E. (2017), “The ontological sense of the concept of 'Measure”, Revista di Filosofia NeoScolastica, no. 2, pp. 471-483.

60. Derrida, J. (2005), Writing and Difference, Routledge Publ., London, New York, UK.

61. Bakeeva, E. V. (2002), Understanding as an Existential Problem, Ural State University Press, Ekaterinburg. (In Russian).

62. Tillich, P. (1980), The Courage to Be, Yale University Press, New Haven, London.

63. Aristotle (1959), Politics, William Heinemann Publ., London.

64. Simmel, G. (1908), Der Mensch als Feind, available at: http://socio.ch/sim/verschiedenes/1907/feind. htm (accessed: 06.08.2018).

65. Bakhtin, M. M. (1990), "Author and Hero in Aesthetic Activity", Art and Answerability, University of Texas Press, Austin, Slavic Ser., no. 9, pp. 4-256.

66. Fromm, E. (1959), Values, Psychology and Human Existence, available at: https://opus4.kobv.de/ opus4-Fromm/files/991/1959b-eng.pdf (accessed: 06.08.2018).

67. Fromm, E. (2008), To Have or to Be?, Continuum Publ., London, New York.

68. Heidegger, M. (1977), “The Turning”, The Question Concerning Technology and Other Essays, Garland Publishing Inc., New York, London, pp. 36-49.

69. Kierkegaard, S. (1992), Either/Or: A Fragment of Life, Penguin Classics, London.

70. Leibniz, G. W. (1898), The Monadology, English translation by Robert Latta, 1898, available at: http:// home.datacomm.ch/kerguelen/monadology/monadology.html (accessed: 06.08.2018). 
71. Heidegger, M. (2000), “Letter on Humanism”, Global Religious Vision, vol. I/I, pp. 83-109.

Received: January 29, 2019

Accepted: June 13, 2019

Author's information:

Ekaterina V.Biricheva — PhD, Researcher; e.v.biricheva@mail.ru

\section{Природа конфликта: онтологический парадокс и экзистенциальное усилие принятия}

\section{Е.В.Биричева}

Институт философии и права Уральского отделения Российской академии наук, Российская Федерация, 620219, Екатеринбург, ул. С. Ковалевской, 16

Для цитирования: Biricheva E. V. The nature of conflict: Ontological paradox and existential effort of acceptance // Вестник Санкт-Петербургского университета. Философия и конфликтология. 2019. Т. 35. Вып. 4. С. 607-625. https://doi.org/10.21638/spbu17.2019.407

В статье исследуется фундаментальная природа конфликта в русле экзистенциальнофеноменологического подхода. Несмотря на то что проводилось огромное количество исследований, посвященных феномену конфликта, внимания его взаимосвязи с онтологическим парадоксом не уделялось. В данном контексте осуществляется попытка определить единое основание для понимания природы конфликта посредством переосмысления специфического положения человека в бытии. Это становится возможным благодаря разворачиванию комплексной экзистенциально-феноменологической методологии, состоящей в описании опыта участного переживания парадоксальной природы конфликта. Очевидно, что в конфликте происходит столкновение противоположностей, несовозможностей, противоречащих друг другу сторон. Однако где берут начало и где располагаются эти противоположности - в «социальном измерении» между людьми или же фундаментальная парадоксальность укоренена в каждом? В ходе поиска ответов на подобные вопросы показывается, что равно непродуктивны как игнорирование (избегание) осмысления такой ситуации, так и спешка срочного разрешения конфликта, искусственный выбор одной из противоположностей парадокса в качестве ценностно более значимой. Возможным решением представляется работа с онтологическим парадоксом в плане его феноменологического тщательного разбора и экзистенциального усилия принятия принципиальной никогда-до-конца-неразрешимости конфликта. Тем не менее последнее показывает парадоксальный путь продуктивного имения дела с человеческой конфликтностью, позволяющий глубоко понять ее природу в категориях конечности, полноты, «внутренней войны», собственного состояния и усилия приятия. Данный подход может быть в дальнейшем применен как в философских, так и в научных исследованиях на основе представленных категорий. Например, значительный интерес составляет исследование таких феноменов, как кризис, привычка, изменение, инновация и т. д., в свете настройки собственного состояния и усилия принятия.

Ключевые слова: конфликт, природа конфликта, экзистенциально-феноменологический подход, онтологический парадокс, усилие принятия.

Статья поступила в редакцию 29 января 2019 г.; рекомендована в печать 13 июня 2019 г.

Контактная информация:

Биричева Екатерина Вячеславовна - канд. филос. наук, науч. сотр.; e.v.biricheva@mail.ru 